OPEN ACCESS

Edited by:

Francisco Javier Medina, Spanish National Research Council,

Spain

Reviewed by:

Chiara Amitrano,

University of Naples Federico II, Italy

Galina Shevchenko,

National Academy of Sciences of

Ukraine, Ukraine

*Correspondence:

Raymond M. Wheeler

Raymond.m.wheeler@nasa.gov

Specialty section:

This article was submitted to Astrobiology,

a section of the journal

Frontiers in Astronomy and Space

Sciences

Received: 01 July 2021 Accepted: 14 October 2021 Published: 10 November 2021

Citation:

Johnson CM, Boles HO, Spencer LE,

Poulet L, Romeyn M, Bunchek JM,

Fritsche R, Massa GD, O'Rourke A and

Wheeler RM (2021) Supplemental

Food Production With Plants: A

Review of NASA Research.

Front. Astron. Space Sci. 8:734343.

doi: $10.3389 /$ fspas.2021.734343

\section{Supplemental Food Production With Plants: A Review of NASA Research}

\author{
Christina M. Johnson ${ }^{1}$, Haley O. Boles ${ }^{2}$, LaShelle E. Spencer ${ }^{3}$, Lucie Poulet ${ }^{1}$, \\ Matthew Romeyn ${ }^{4}$, Jess M. Bunchek ${ }^{5}$, Ralph Fritsche ${ }^{4}$, Gioia D. Massa ${ }^{4}$, Aubrie O'Rourke ${ }^{4}$ \\ and Raymond M. Wheeler ${ }^{4 *}$ \\ ${ }^{1}$ NASA Postdoctoral Program, Universities Space Research Association, Kennedy Space Center, FL, United States, \\ ${ }^{2}$ Microbiology and Cell Science, University of Florida, Gainesville, FL, United States, ${ }^{3}$ Amentum Services Inc., Kennedy Space \\ Center, FL, United States, ${ }^{4}$ NASA Exploration Research and Technology, Kennedy Space Center, FL, United States, \\ ${ }^{5}$ Southeastern Universities Research Association, Kennedy Space Center, FL, United States
}

Bioregenerative life-support systems for space have been investigated for 60 years, and plants and other photosynthetic organisms are central to this concept for their ability to produce food and $\mathrm{O}_{2}$, remove $\mathrm{CO}_{2}$, and help recycle wastewater. Many of the studies targeted larger scale systems that might be used for planetary surface missions, with estimates ranging from about 40 to $50 \mathrm{~m}^{2}$ (or more) of crop growing area needed per person. But early space missions will not have these volumes available for crop growth. How can plants be used in the interim, where perhaps $<5 \mathrm{~m}^{2}$ of growing area might be available? One option is to grow plants as supplemental, fresh foods. This could improve the quality and diversity of the meals on the International Space Station or on the Lunar surface, and supply important nutrients to the astronauts for missions like Mars transit, and longer duration Martian surface missions. Although plant chambers for supplemental food production would be relatively small, they could provide the bioregenerative research community with platforms for testing different crops in a space environment and serve as a stepping stone to build larger bioregenerative systems for future missions. Here we review some of NASA's research and development (ground and spaceflight) targeting fresh food production systems for space. We encourage readers to also look into the extensive work by other space agencies and universities around the world on this same topic.

Keywords: crop, nutrient, salad, veggie, greenhouse, sustainable, ECLSS, controlled ecological life-support systems

\section{INTRODUCTION}

Bioregenerative life support systems (BLSS) have been one of the most enduring life science research themes since the beginning of the space era in the 1950's (Myers, 1954). The use of photosynthetic organisms for food and oxygen production, along with $\mathrm{CO}_{2}$ removal and water processing is central to this concept (Miller and Ward, 1966; Salisbury et al., 1997) and in 1962 discussions began on what crop plants to consider for space missions (Pilgrim and Johnson, 1962). But opportunities to test BLSS at a relevant scale in space have been limited due to volume and mass constraints of the spacecraft. Modest efforts at space crop production on board NASA's Space Shuttle, the Russian Mir station, and the International Space Station (ISS) have been underway since the 1990's, but most have been short duration studies and all have been limited due to volume, mass, and power constraints. To date, life-support systems for spacecraft and space stations have been based on physico-chemical (PC) principles, some of them regenerative, others relying on resupply (Shaw et al., 2020). For 
example, urine from the crew on the ISS is currently processed through a vapor compression distillation system and purified to recover potable water (Carter et al., 2018). Here we review only plant related testing in space for food production and eventual BLSS applications.

\section{Food Production in Bioregenerative Life Support Systems}

To supply food on space missions, the only option to date has been stowage and resupply of packaged, stabilized foods (Perchonok et al., 2012). Currently, the ISS receives several resupply missions of food each year, but this approach will be more costly as mission durations and distances increase (Perchonok et al., 2012). About $40-50 \mathrm{~m}^{2}$ of crops grown under high light intensities would be needed to produce enough dietary calories for one human, and when coupled with insects to degrade inedible biomass and provide supplemental protein, the area could be reduced to $35-40 \mathrm{~m}^{2}$ per person (Salisbury et al., 1997; Wheeler et al., 2008; Fu et al., 2016). Plantings of this size would also supply all the $\mathrm{O}_{2}$ production and $\mathrm{CO}_{2}$ removal for one human. However, these BLSS studies have all been ground-based, and opportunities to test and implement them in space have been limited. A logical approach might be to sequentially develop smaller BLSS capabilities on space missions where PC life-support systems are already in place; then as durations and distances increase, expand BLSS components where applicable (Gitelson et al., 1995; Wheeler, 2002; Morrow et al., 2004). While earlier approaches focused on larger scale food production for more full life-support (carbohydrate, fat, protein), micronutrients were not given as high a priority (e.g., Mitchell et al., 1996; Salsibury and Clark, 1996). But supplying even smaller amounts of fresh produce could supplement micronutrients such as vitamins $\mathrm{C}$ and B1, which may degrade in the packaged diet, provide dietary antioxidants, and improve the overall acceptability of meals for the crew (Cooper et al., 2017). Extensive work has been done by other space agencies and universities around the world to address these same issues (Wheeler, 2017). For example, the 1970's Oasis tests on the Russian Salyut Space Station were the first attempts at a human-monitored plant BLSS research in space (Porterfield et al., 2003). Here we review some NASA sponsored ground-based and space research with plants that could be used as supplemental fresh foods on early missions.

\section{Preparing Crops for Space: The Concept of Crop Readiness Level}

Space brings with it unique environmental constraints for crops. This inspired the concept of a Crop Readiness Level or CRL (Wheeler and Strayer, 1997), which is a maturation scale analogous to technology readiness levels (TRL) but for crops and BLSS. For example, short or dwarf growth, high harvest index, high yields, organoleptic acceptance, good nutrient content, and ability to control microbial contaminants are all desirable traits for the selection and maturation of CRL for space (Romeyn et al., 2019; Spencer et al., 2021). The current scale is focused on ISS and Mars transit needs, but surface settings with larger BLSS crop systems might consider different criteria or factors appropriate for those settings, such as higher macronutrient content, ability to grow in multispecies plantings, or radiation tolerance. Like applying TRL for aerospace hardware, a CRL approach provides a logical progression of testing for future space crops.

\section{Historical Context of Preparing Crops for Spaceflight: Ground-Based Research}

Decades of ground and flight research have gone into our current supplemental crop growth systems on the ISS. Around 1980, NASA started its Controlled Ecological Life-Support Systems (CELSS) program (MacElroy and Bredt, 1984). The CELSS Program focused largely on BLSS research for surface missions and agronomic crops that might be grown in large plantings (MacElroy et al., 1990; Wheeler, 2017), but CELSS also proposed a smaller "rack" sized plant system for growing supplemental food crops for near term and Mars transit missions. The term "salad machine" or "vegetable production unit" was used for this concept (Kliss and MacElroy, 1990).

Unlike the staple crops tested by NASA in the 1980's and 1990 's (e.g., wheat, soybean, potato, peanut, sweet potato), leafy greens and small fruit crops (e.g., tomato and pepper) can be grown on the ISS and early missions to supplement the crew's diet. These supplemental food crops have a short shelf life but can have a high impact on the diet (Cooper et al., 2012). NASA ground testing included species such as spinach, lettuce, chard, green onion, leafy mustards such as pak choi, mizuna, and Chinese cabbage, radish, beet, dwarf tomato, dwarf pepper, strawberry, and dwarf plum trees (Knight and Mitchell, 1983; Gilrain et al., 1999; Subbarao et al., 1999; Goins and Yorio, 2000; Richards et al., 2004; Massa et al., 2006; Hummerick et al., 2010; Graham et al., 2015; Massa et al., 2016; Graham and Wheeler, 2016). To date, many of the leafy greens and "Red Robin" tomato have performed very well in these studies (Spencer et al., 2019; Spencer et al., 2020).

\section{CROP PHYSIOLOGICAL CONCERNS}

\section{Impact of Atmospheric $\mathrm{CO}_{2}$ Concentrations}

Significant vegetable crop testing by NASA focused on the effects of $\mathrm{CO}_{2}$ on crop growth and development (McKeehen et al., 1996; Spencer et al., 2019; Burgner et al., 2020). Elevating the $\mathrm{CO}_{2}$ from ambient levels $\sim 400 \mathrm{ppm}$ to $1,000-2000 \mathrm{ppm}$ increased growth and yield for most crops, as expected. But yields of some crops like radish and lettuce dropped at super-elevated $\mathrm{CO}_{2}$ concentrations, e.g., 5,000 and 10,000 ppm, compared to 1,000 ppm (Mackowiak et al., 1994). Thus for typical $\mathrm{CO}_{2}$ levels on the ISS ( 3,000 ppm), most of these crops should grow well. But for Chinese cabbage, $\mathrm{cv}$. Tokyo Bekana, the combination of moderately elevated $\mathrm{CO}_{2}$ (900 ppm) and LED lighting decreased growth compared to lower $\mathrm{CO}_{2}$ levels (Burgner et al., 2020). This response highlights the importance of conducting thorough ground testing prior to spaceflight (Romeyn et al., 2019). 


\section{TIMELINE OF PROJECTS}

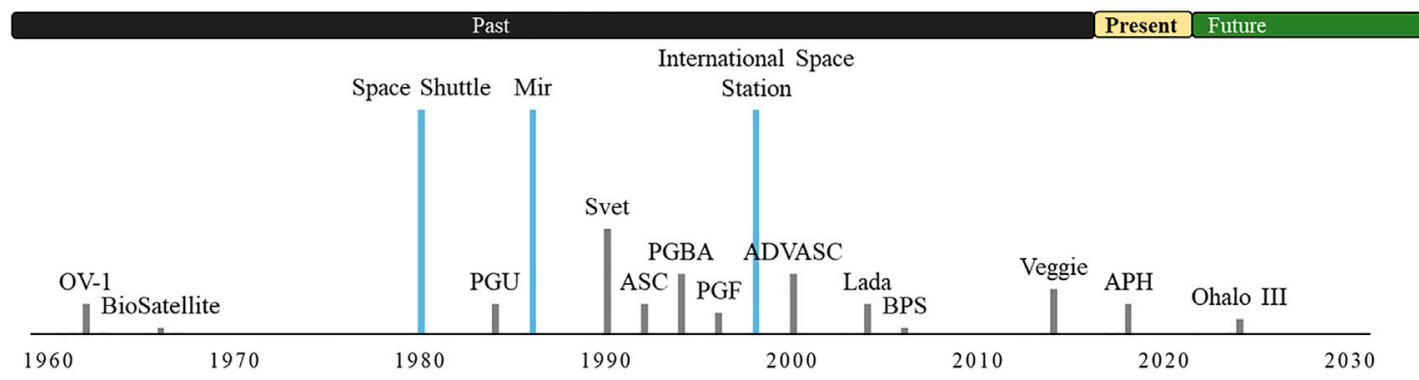

FIGURE 1 | Timeline of projects. Spaceflight hardware for bioregenerative crop production from 1960-2030. Past (black), present (yellow), and future (green) are indicated above the timeline. Platforms are indicated with a blue line while plant-specific hardware is indicated by a gray line. Length of the gray line represents the relative length of time that the hardware was/has been in operation. Orbital Vehicle 1 (OV-1; US Air Force), BioSatellite I and II (NASA), Plant Growth Unit (PGU; NASA), Svet (Roscosmos), Astroculture (ASC; Univ. Wisconsin/NASA), Plant Generic Bioprocessing Apparatus (PGBA; BioServe/NASA), Plant Growth Facility (PGF; NASA), Advanced Astroculture (ADVASC; Univ. Wisconsin/NASA), Lada (Roscosmos), Biomass Production System (BPS; NASA), Veggie (NASA), Advanced Plant Habitat $(\mathrm{APH} ; \mathrm{NASA})$. Veggie and APH are currently in use on the International Space Station.

\section{Plant Lighting}

Using light emitting diodes (LEDs) to grow plants was proposed and patented through a NASA Commercialization Center at the University of Wisconsin (Barta et al., 1992). LEDs were first used in the Astroculture (ASC) plant chamber aboard the Space Shuttle (Morrow et al., 1995) then the Advanced Astroculture Chamber (ADVASC) (Link et al., 2003), and later the Veggie and Advanced Plant Habitat for the ISS, both of which are currently flying aboard the ISS (Massa et al., 2016; Morrow et al., 2016). To support the development of LED lighting for space, NASA sponsored ground testing from the early 1990's through the mid 2000's with leafy greens and other crops (Goins et al., 1997; Kim et al., 2004; Massa et al., 2008). These studies showed that both red and blue light improved plant photosynthesis and growth (Bula et al., 1991; Dougher and Bugbee, 2001; Yorio et al., 2001; Douglas et al., 2016). Subsequent LED studies revealed important roles for green and far-red light as well (Spencer et al., 2020). Recent NASA research showed that supplementing with far-red LEDs can act like adding more photosynthetically active radiation-PAR (400-700 nm) (Zhen and Bugbee, 2020), and that LEDs can achieve remarkable efficiencies $(>3 \mu \mathrm{mol} / \mathrm{J})$, which could greatly reduce electrical power needs for BLSS (Kusuma et al., 2020). This has far-reaching implications for future missions. In addition to electric lighting systems, solar lighting techniques that use concentrators and fiber optics were also explored for growing crops (Cuello et al., 2000; Nakamura et al., 2009).

Regardless of the lighting approach, nearly all these studies showed greater yields in response to increased PAR (Knight and Mitchell, 1983; Knight and Mitchell, 1988; Richards et al., 2004). Although some leafy greens are prone to physiological disorders like leaf tip burn at higher PAR (Barta and Tibbitts, 1991; Frantz et al., 2004), this key relationship between PAR and yield becomes a driving factor for planning crop systems for space. For NASA's Veggie plant chamber on the ISS, the PAR is adjustable up to $\sim 450 \mu \mathrm{mol} \mathrm{m}^{-2} \mathrm{~s}^{-1}$ depending on distance between the plants and lights, but has typically been operated between 200 and $300 \mu \mathrm{mol} \mathrm{m}{ }^{-2} \mathrm{~s}^{-1}$ (Massa et al., 2016).

\section{NASA'S PAST, PRESENT, AND PLANNED PLANT CHAMBERS FOR SPACE}

The first attempt to test BLSS concepts in space was with the Orbital Vehicle (OV-1) satellite mission in 1966, where NASA and the US Air Force monitored photosynthetic and respiratory gas exchange between duckweed (Spirodella) and Chlorella aglae (Ward et al., 1970). The subsequent BioSatellite 2 experiments tested wheat seedlings and pepper plants in microgravity (Conrad, 1968; Johnson and Tibbitts, 1968), but these were short flights with limited data recovery. NASA funded investigators F.B. Salisbury and G.E. Bingham also collaborated with Russian colleagues for a series of tests in the Svet plant chamber on Mir space station through much of the 1990's with research focusing on wheat production (Bingham et al., 1996, 2000). With the Shuttle program came more frequent trips to space and more chamber options for plant growth, such as the Plant Growth Unit (PGU) and subsequent Plant Growth Facility (PGF) (Halstead and Dutcher, 1987; Paul et al., 2001). These chambers were primarily for space and gravitational research. In comparison, the Astroculture (ASC) and Plant Generic Bioprocessing Apparatus (PGBA) were also used on the Shuttle but more focused on BLSS concepts (Bula et al., 1991; Morrow et al., 1995; Hoehn et al., 1997; Porterfield et al., 2003; Zabel et al., 2016) (Figure 1).

Compared to standard gravity, watering systems for $\mu$-gravity must deal with water containment, the lack of natural drainage and impaired aeration of the rootzones (Bingham et al., 2000; Steinberg et al., 2002; Jones et al., 2011). This began ground testing of porous membranes, tubes, or plates to contain the water and allow capillary movement to the roots (Wright et al., 1988; Dreschel and Sager 1989; Koontz et al., 1990), as well as flight testing of hybrid approaches that use porous tubes to sub-irrigate a solid rooting matrix (Morrow et al., 1992; Bula et al., 1991). ASC and PGBA also used porous thermo-electric plates to cool and dehumidify the air, while recycling the condensate back to the plants (Morrow et al., 1995; Hoehn et al., 1997; Conrad, 1968; Dreschel and Sager 1989;Johnson and Tibbitts, 1968; Khodadad et al., 2020; Koontz et al., 1990; Morrow et al., 1992; Schuerger et al., 2021; Stutte et al., 2005; Wright et al., 1998). 
TABLE 1 | NASA crops grown in spaceflight in Veggie and APH.

\begin{tabular}{|c|c|c|c|}
\hline Crop & Scientific Name & Experiments & $\begin{array}{l}\text { Experiment } \\
\text { Flight Grow Dates }\end{array}$ \\
\hline Red Romaine Lettuce & Lactuca sativa cv. Outredgeous & $\begin{array}{l}\text { VEG-01A } \\
\text { VEG-01B } \\
\text { VEG-03A } \\
\text { VEG-03D } \\
\text { VEG-03E } \\
\text { VEG-03F } \\
\text { VEG-03I } \\
\text { VEG-03J }\end{array}$ & $\begin{array}{l}\text { May 8, 2014-June 10, } 2014 \\
\text { July 8, 2015-Aug. 10, } 2015 \\
\text { Oct. 25, 2016-Dec. 28, } 2016 \\
\text { Sept. 26, 2017-Nov. 23, } 2017 \\
\text { Feb. 5, 2018-April 6, } 2018 \\
\text { Feb. 9, 2018-April 9, } 2018 \\
\text { Jan. 4, 2021-Feb. 2, } 2021 \\
\text { Jan. 4, 2021-Feb. 2, } 2021\end{array}$ \\
\hline Green Leaf Lettuce & Lactuca sativa cv. Waldmann's Green & $\begin{array}{l}\text { VEG-03D } \\
\text { VEG-03E } \\
\text { VEG-03F }\end{array}$ & $\begin{array}{l}\text { Sept. 26, 2017-Nov. 23, } 2017 \\
\text { Feb. 5, 2018-April 6, } 2018 \\
\text { Feb. 9, 2018-April 9, } 2018\end{array}$ \\
\hline Dwarf Romaine & Lactuca sativa cv. Dragoon & $\begin{array}{l}\text { VEG-03G } \\
\text { VEG-03I }\end{array}$ & $\begin{array}{l}\text { Oct. 25, 2018-Nov. 28, } 2018 \\
\text { Jan. 4, 2021-Feb. 2, } 2021\end{array}$ \\
\hline Zinnia & Zinnia hybrida cv. Profusion & VEG-01C & Nov. 16, 2015-Feb 14, 2016 \\
\hline Chinese Cabbage & Brassica rapa var. Chinensis cv. Tokyo Bekana & $\begin{array}{l}\text { VEG-03B } \\
\text { VEG-03C }\end{array}$ & $\begin{array}{l}\text { Jan. 20, 2017-May 31, } 2017 \\
\text { April 3, 2017-May 31, } 2017\end{array}$ \\
\hline Mizuna Mustard & Brassica rapa var. japonica & $\begin{array}{l}\text { VEG-03D } \\
\text { VEG-03E } \\
\text { VEG-04A } \\
\text { VEG-04B }\end{array}$ & $\begin{array}{l}\text { Sept. 26, 2017-Nov. 23, } 2017 \\
\text { Feb. 5, 2018-April 6, } 2018 \\
\text { June 4, 2019-July 9, } 2019 \\
\text { Oct. 1, 2019-Nov. 28, } 2019\end{array}$ \\
\hline Red Kale & Brassica napus cv. Red Russian Kale & $\begin{array}{l}\text { VEG-03G } \\
\text { VEG-03I }\end{array}$ & $\begin{array}{l}\text { Oct. 25, 2018-Nov. 28, } 2018 \\
\text { Jan. 4, 2021-Feb. 2, } 2021\end{array}$ \\
\hline Wasabi Mustard & Brassica juncea cv. Wasabi & $\begin{array}{l}\text { VEG-03H } \\
\text { VEG-03I }\end{array}$ & $\begin{array}{l}\text { March 9, } 2019 \text { - April 6, } 2019 \\
\text { Jan. 4, } 2021 \text { - Feb. 2, } 2021\end{array}$ \\
\hline Dwarf Pak Choi & Brassica rapa var. Chinensis cv. Extra Dwarf & $\begin{array}{l}\text { VEG-03H } \\
\text { VEG-03I } \\
\text { VEG-03L }\end{array}$ & $\begin{array}{l}\text { March 9, 2019-April 6, } 2019 \\
\text { Jan. 4, 2021-Feb. 2, } 2021 \\
\text { Feb. 8, 2021-Apr. 13, } 2021\end{array}$ \\
\hline Amara Mustard/Ethiopian Kale & Brassica carinata & VEG-03K & Feb. 8, 2021-Apr. 13, 2021 \\
\hline Radish & Raphanus sativus & $\mathrm{PH}-02$ & Nov. 3, 2020-Nov. 30, 2020 \\
\hline Pepper & Capsicum annuum cv. Española Improved & $\mathrm{PH}-04$ & July 12, 2021 \\
\hline
\end{tabular}

By 2000, plant growth systems were launched to the ISS. First was the ADVASC (Link et al., 2003) and then the Biomass Production System (BPS) (Stutte et al., 2005), both of which were double, mid-deck, locker-sized chambers. In 2014 the Veggie chamber was added to the ISS, with a second unit added in 2017. The Advanced Plant Habitat (APH), a quad, locker-sized chamber that provides a wide range of environmental control, was based on Astroculture principles (Zhou et al., 1998) and installed on the ISS in 2017 (Massa et al., 2016; Morrow et al., 2016). Unlike the ADVASC, BPS, and $\mathrm{APH}, \mathrm{Veggie}$ was intended to be collapsible for stowage, open to the cabin atmosphere, and easily accessible for the crew, much like the Russian Svet and Lada systems (Bingham et al., 1996; 2000) To date, Veggie has been used more than any other chamber in space to study fresh food production for astronauts.

\section{Recent NASA Spaceflight Studies of Supplemental Food Production}

To date, the series of 12 leafy green tests in NASA's Veggie chamber on the ISS included lettuce (several cultivars), mizuna, Chinese cabbage, wasabi mustard, red Russian kale, amara mustard, and pak choi (Table 1). The first studies used "Outredgeous" red romaine lettuce and an ornamental crop, "Profusion" zinnia (Massa et al., 2015). Tests with Chinese cabbage showed leaf chlorosis on some of the plants (Burgner et al., 2020). Analyses of nutrient content of red romaine lettuce grown in Veggie found no significant difference between the ground control and spaceflight treatment of each experiment. Some growth differences were found across the three studies, each conducted a year apart, and are attributed to different environmental conditions (Khodadad et al., 2020). The crop microbiome did vary, with a considerably more diverse microbial community found on space ground produce, especially the leaves. Lettuce growth improved with better approaches to watering by astronauts. Throughout most of the Veggie tests, water management has been challenging, with lettuce having insufficient water in some early tests, while zinnia plants had too much, primarily due to a ventilation system failure (Schuerger et al., 2021). The baseline Veggie watering system is a passive wicking design, where water from a reservoir wicks to plant pillows, which are filled with arcillite media and controlled-released fertilizer (Massa et al., 2017a; Massa et al., 2017b). The capillary watering approach has thus 
far been inconsistent due to materials and design issues. These issues have not been addressed to date so Veggie experiments have relied largely on direct manual watering. The watering system in APH consists of porous tubes surrounded by arcillite media (Morrow et al., 2016), and to date it has worked well. Recently the radish plants grown in APH were consumed by astronauts (John et al., 2021). A second crop, chile peppers (Spencer et al., 2019), began growing for the first time in APH in orbit on July 12, 2021 (Table 1).

\section{Ohalo III}

NASA's next step toward space crop production will be the Ohalo III chamber, targeted for the ISS as early as 2024. This rack-sized crop production system will be atmospherically closed to recycle transpired humidity and will contain various automation and sensing capabilities. Ohalo III is designed to be evolvable and expandable and will initially test different water delivery and volume optimization concepts for growing plants in microgravity. As a permanent addition to the ISS, Ohalo III should be able to investigate operational challenges associated with the sustained production of crops in space and will hopefully achieve the long desired "vegetable production unit" for a Mars transit mission (Kliss and MacElroy, 1990; Kliss et al., 2000).

\section{DISCUSSION}

NASA has sponsored extensive research on growing various species of leafy vegetables and small fruits in controlled environment chambers. This research revealed the importance of managing water and nutrient supplies to the plants, the effects of elevated and super-elevated $\mathrm{CO}_{2}$ on plants, and the profound influence of light on crop growth and development. This in turn has driven the development and testing of LED lighting and other new technologies for space crop production. Other key gaps exist in our knowledge base, such as the effects of reduced gravity on the plants and their support systems, such as water delivery, and the effects of space radiation. Most of this testing occurred in "ground" settings, but small plant chambers have been built and tested in space. These chambers have become successively larger with better environmental control, but none have been used with the sole intent for providing fresh food for the astronauts. Exploratory tests with the Veggie plant chamber are

\section{REFERENCES}

Barta, D. J., Tibbitts, T. W., Bula, R. J., and Morrow, R. C. (1992). Evaluation of Light Emitting Diode Characteristics for a Space-Based Plant Irradiation Source. Adv. Space Res. 12, 141-149. doi:10.1016/0273-1177(92)90020-x

Barta, D. J., and Tibbitts, T. W. (1991). Calcium Localization in Lettuce Leaves with and without Tipburn: Comparison of Controlled-Environment and FieldGrown Plants. J. Am. Soc. Hortic. Sci. 116, 870-875. doi:10.21273/ jashs.116.5.870

Bingham, G. E., Jones, S. B., Or, D., Podolski, I. G., Levinskikh, M. A., Sytchov, V. N., et al. (2000). Microgravity Effects on Water Supply and Substrate Properties beginning to do this, but a dedicated "vegetable production unit" with better environmental control is still needed.

\section{Concluding Remarks}

BLSS using plants to generate food and oxygen while recycling $\mathrm{CO}_{2}$ and water will help achieve more autonomous living on other planets; however, developing a large BLSS on surface settings could be decades in the future, and this will be dictated in part by mission architectures of the various space agencies. Nonetheless, continued ground research on these systems is needed to understand their integration with other environmental control technologies, their sustainability, and their costs in terms of mass, power, volume, and crew time. Part of the evolution toward these BLSS systems will be testing smaller components or subsystems in space settings like the ISS and early surface missions. A logical stepping stone in this progression will be using smaller plant chambers to provide supplemental, fresh foods to augment stored foods. These fresh foods could reduce diet fatigue and provide key nutrients that degrade in the packaged food supplies. Understanding the operation, cost, and sustainability of these smaller food-crop production systems will provide critical information for evolving toward a larger BLSS of the future.

\section{AUTHOR CONTRIBUTIONS}

All authors listed have made a substantial, direct, and intellectual contribution to the work and approved it for publication.

\section{FUNDING}

Funding for this review manuscript provided through NASA Biological and Physical Sciences Program, and NASA's Advanced Exploration Systems Program.

\section{ACKNOWLEDGMENTS}

The authors would like to acknowledge the efforts of all those who have contributed to space crop production around the world.

in Porous Matrix Root Support Systems. Acta Astronautica 47 (11), 839-848. doi:10.1016/s0094-5765(00)00116-8

Bingham, G. E., Salisbury, F. B., Campbell, W. F. W., Carman, J. G., Bubenheim, D. L., Yendler, B., et al. (1996). The Spacelab-Mir-1 "Greenhouse-2" Experiment. Adv. Space Res. 18, 225-232. doi:10.1016/0273-1177(95)00881-e

Bula, R. J., Morrow, R. C., Tibbitts, T. W., Barta, D. J., Ignatius, R. W., and Martin, T. S. (1991). Light-Emitting Diodes as a Radiation Source for Plants. HortSci 26 (2), 203-205. doi:10.21273/hortsci.26.2.203

Burgner, S. E., Nemali, K., Massa, G. D., Wheeler, R. M., Morrow, R. C., and Mitchell, C. A. (2020). Growth and Photosynthetic Responses of Chinese Cabbage (Brassica Rapa L. Cv. Tokyo Bekana) to Continuously Elevated Carbon Dioxide in a Simulated Space Station "Veggie" 
Crop-Production Environment. Life Sci. Space Res. 27, 83-88. doi:10.1016/j.lssr.2020.07.007

Carter, D., Williamson, J., Hill, J., Graves, R., Long, D., and Clifton, J. (2018). "Upgrades to the ISS Urine Processor Assembly," in Intl. Conf. on Environ. Systems ICES-2018-089, Albuquerque, NM, July.

Cooper, M., Perchonok, M., and Douglas, G. L. (2017). Initial Assessment of the Nutritional Quality of the Space Food System over Three Years of Ambient Storage. npj Microgravity 3, 1-4. doi:10.1038/s41526-017-0022-z

Cooper, M. R., Catauro, P., and Perchonok, M. (2012). Development and Evaluation of Bioregenerative Menus for Mars Habitat Missions. Acta Astronautica 81, 555-562. doi:10.1016/j.actaastro.2012.08.035

Conrad, H. M. (1968). Biochemical Changes in the Developing Wheat Seedling in the Weightless State. BioScience 18 (6), 645-652. doi:10.2307/1294316

Cuello, J. L., Yang, Y., Ono, E., Jordan, K. A., and Nakamura, T. (2000). Hybrid Solar and Xenon-Metal Halide Lighting for Lunar and Martian Bioregenerative Life Support. SAE, Technical Paper 2000-01-2426. doi:10.4271/2000-01-2426

Dougher, T. A. O., and Bugbee, B. (2001). Differences in the Response of Wheat, Soybean and Lettuce to Reduced Blue Radiation. Photochem. Photobiol. 73, 199-207. doi:10.1562/0031-8655(2001)073<0199:ditrow>2.0.co;2

Douglas, G. L., Cooper, M., Bermudez-Aguirre, D., and Sirmons, T. (2016). Risk of Performance Decrement and Crew Illness Due to an Inadequate Food System. Available at: https://humanresearchroadmap.nasa.gov/evidence/ (Accessed October 20, 2021).

Dreschel, T. W., and Sager, J. C. (1989). Control of Water and Nutrients Using a Porous Tube: A Method for Growing Plants in Space. HortScience 24, 944-947.

Frantz, J. M., Ritchie, G., Cometti, N. N., Robinson, J., and Bugbee, B. (2004). Exploring the Limits of Crop Productivity: Beyond the Limits of Tipburn in Lettuce. Jour. Am. Soc. Hort. Sci. 129, 331-338. doi:10.21273/jashs.129.3.0331

Fu, Y., Li, L., Xie, B., Dong, C., Wang, M., Jia, B., et al. (2016). How to Establish a Bioregenerative Life Support System for Long-Term Crewed Missions to the Moon or Mars. Astrobiology 16, 925-936. doi:10.1089/ast.2016.1477

Gilrain, M. R., Hogan, J. A., Cowan, R. M., Finstein, M. S., and Logendra, L. S. (1999). Preliminary Study of Greenhouse Grown Swiss Chard in Mixtures of Compost and Mars Regolith Simulant. SAE, Technical Paper No. 1999-012021. doi:10.4271/1999-01-2021

Gitelson, J. I., V, B., Grigoriev, A. I., Lisovsky, G. M., Manukovsky, N. S., Sinyak, Y. U. E., et al. (1995). Biological-physical-chemical Aspects of a Human Life Support System for a Lunar Base. Acta Astronautica 37, 385-394. doi:10.1016/ 0094-5765(95)00053-3

Goins, G. D., Yorio, N. C., Sanwo, M. M., and Brown, C. S. (1997). Photomorphogenesis, Photosynthesis, and Seed Yield of Wheat Plants Grown Under Red Light-Emitting Diodes (LEDs) with and without Supplemental Blue Lighting. J. Exp. Bot. 48, 1407-1413. doi:10.1093/jxb/ 48.7.1407

Goins, G. D., and Yorio, N. C. (2000). Spinach Growth and Development Under Innovative Narrow- and Broad-Spectrum Lighting Sources. SAE, Technical Paper No. 2000-01-2290. doi:10.4271/2000-01-2290

Graham, T., Scorza, R., Wheeler, R. M., Smith, B. J., Dardick, C., Dixit, A., et al. (2015). Over-Expression of FT1 in Plum (Prunus Domestica) Results in Phenotypes Compatible with Spaceflight: A Potential New Candidate Crop for Bioregenerative Life-Support Systems. Gravit. Space Res. 3 (1), $39-50$.

Graham, T., and Wheeler, R. (2016). Root Restriction: A Tool for Improving Volume Utilization Efficiency in Bioregenerative Life-Support Systems. Life Sci. Space Res. 9, 62-68. doi:10.1016/j.lssr.2016.04.001

Halstead, T. W., and Dutcher, F. R. (1987). Plants in Space. Annu. Rev. Plant Physiol. 38, 317-345. doi:10.1146/annurev.pp.38.060187.001533

Hoehn, A., Chamberlain, D. J., Forsyth, S. W., Hanna, D. S., Scovazzo, P., Horner, M. B., Stodieck, L. S., Todd, P., Heyenga, A. G., Kliss, M. H., Bula, R., and Yetka, R. (1997). "10 Day Flight Performance of the Plant Generic Bioprocessing Apparatus (PGBA) Plant Growth Facility Aboard STS-77," in AIP Conference Proceedings, Lake Tahoe, NV, July (American Institute of Physics), 387, 1005-1010. doi:10.1063/1.51916

Hummerick, M., Garland, J., Bingham, G., Sychev, V., and Podolsky, I. (2010). "Microbiological Analysis of Lada Vegetable Production Units (VPU) to Define Critical Control Points and Procedures to Ensure the Safety of Space Grown Vegetables," in Amer. Inst. Aeronautics Astronautics, 40th ICES meeting, Barcelona, Spain, July 2010. AIAA-2010-6253.
John, S., Abou-Issa, F., and Hasenstein, K. H. (2021). Space Flight Cultivation for Radish (Raphanus Sativus) in the Advanced Plant Habitat. Gravit. Space Res. 9 (1), 121-132. doi:10.2478/gsr-2021-0010

Johnson, S. P., and Tibbitts, T. W. (1968). The Liminal Angle of a Plagiogeotropic Organ under Weightlessness. BioScience 18 (6), 655-661. doi:10.2307/ $1294310.2307 / 1294318$

Jones, S. B., Or, D., Heinse, R., and Tuller, M. (2011). Beyond Earth: Designing Root Zone Environments for Reduced Gravity Conditions. Vadose Zone J. 11, 17. doi:10.2136/vzj2011.0081

Khodadad, C. L. M., Hummerick, M. E., Spencer, L. E., Dixit, A. R., Richards, J. T., Romeyn, M. W., et al. (2020). Microbiological and Nutritional Analysis of Lettuce Crops Grown on the International Space Station. Front. Plant Sci. 11, 199. doi:10.3389/fpls.2020.00199

Kim, H.-H., Goins, G. D., Wheeler, R. M., and Sager, J. C. (2004). Green-light Supplementation for Enhanced Lettuce Growth under Red- and Blue-LightEmitting Diodes. HortSci 39, 1617-1622. doi:10.21273/hortsci.39.7.1617

Kliss, M., HeyengaHoehn, G. A., and Stodieck, L. (2000). Toward the Development of a "Salad Machine" 2000. SAE, Technical Paper 2006-0308.

Kliss, M., and MacElroy, R. D. (1990). Salad Machine: A Vegetable Production Unit for Long Duration Space Missions. SAE, Technical Paper 901280. Williamsburg, VA, USA. July 1990.

Knight, S. L., and Mitchell, C. A. (1983). Enhancement of Lettuce Yield by Manipulation of Light and Nitrogen Nutrition. HortScience 108, 750-754.

Knight, S. L., and Mitchell, C. A. (1988). Growth and Yield Characteristics of 'Waldmann's Green' Leaf Lettuce under Different Photon Fluxes from Metal Halide or Incandescent + Fluorescent Radiation. Scientia Horticulturae 35, 51-61. doi:10.1016/0304-4238(88)90036-2

Koontz, H. V., Prince, R. P., and Berry, W. L. (1990). A Porous Stainless Steel Membrane System for Extraterrestrial Crop Production. HortSci 25, 707. doi:10.21273/hortsci.25.6.707

Kusuma, P., Pattison, P. M., and Bugbee, B. (2020). From Physics to Fixtures to Food: Current and Potential LED Efficacy. Hortic. Res. 7, 1-9. doi:10.1038/ s41438-020-0283-7

Link, B. M., Durst, S. J., Zhou, W., and Stankovic, B. (2003). Seed-to-Seed Growth of Arabidopsis thaliana on the International Space Station. Adv. Space Res. 31, 2237-2243. doi:10.1016/s0273-1177(03)00250-3

MacElroy, R. D., and Bredt, J. (1984). Current Concepts and Future Directions of CELSS. Adv. Space Res. 4, 221-229. doi:10.1016/0273-1177(84)90566-0

MacElroy, R. D., Martello, N. V., and Smernoff, D. T. (1990). Controlled Ecological Life Support Systems: CELSS' 89 Workshop. NASA Tech. Memorandum 102277,437

Mackowiak, C. L., Ruffe, L. M., Yorio, N. C., and Wheeler, R. M. (1994). Effect of Carbon Dioxide Enrichment on Radish Production Using Nutrient Film Technique (NFT). NASA Technical Memorandum 109198

Morrow, R. C., Bula, R. J., Tibbitts, T. W., and Dinauer, W. R. (1992). A MatrixBased Porous Tube Water and Nutrient Delivery System. SAE Technical Paper 921390. doi:10.4271/921390A Matrix-Based Porous Tube Water and Nutrient Delivery System

Massa, G. D., Dufour, N. F., Carver, J. A., Hummerick, M. E., Wheeler, R. M., Morrow, R. C., et al. (2017a). VEG-01: Veggie Hardware Validation Testing on the International Space Station. Open Agric. 2, 33-41. doi:10.1515/opag-20170003

Massa, G. D., Kim, H.-H., Wheeler, R. M., and Mitchell, C. A. (2008). Plant Productivity in Response to LED Lighting. HortScience 43 (7), 1951-1956. doi:10.21273/hortsci.43.7.1951

Massa, G. D., Mick, M. E., and Mitchell, C. A. (2006). Strawberry Cultivar Analysis: Temperature and Pollination Studies. SAE, Technical Paper 2006-01-2030. doi:10.4271/2006-01-2030

Massa, G. D., Newsham, G., Hummerick, M. E., Morrow, R. C., and Wheeler, R. M. (2017b). Plant Pillow Preparation for the Veggie Plant Growth System on the International Space Station. Gravit. Space Res. 5, 24-34. doi:10.2478/gsr-20170002

Massa, G. D., Wheeler, R. M., Morrow, R. C., and Levine, H. G. (2016). Growth chambers on the International Space Station for Large Plants. Acta Hortic. 1134, 215-222. doi:10.17660/ActaHortic.2016.1134.29

Massa, G. D., Wheeler, R. M., Stutte, G. W., Richards, J. T., Spencer, L. E., Hummerick, M. E., Douglas, G. L., and Sirmons, T. (2015). "Selection of Leafy Green Vegetable Varieties for a Pick-And-Eat Diet Supplement on ISS," in 45th 
International Conference on Environmental Systems ICES-2015-252, Bellevue, Washington, July.

McKeehen, J. D., Smart, D. J., Mackowiak, C. L., Wheeler, R. M., and Nielsen, S. S. (1996). Effect of CO2 Levels on Nutrient Content of Lettuce and Radish. Adv. Space Res. 18, 85-92. doi:10.1016/0273-1177(95)00864-b

Miller, R. L., and Ward, C. H. (1966). "Algal Bioregenerative Systems," in Atmosphere in Space Cabins and Closed Environments. Editor E. Kammermeyer (New York: Appleton-Century-Croft Pub.), 186-222. doi:10.1007/978-1-4684-1372-4_9

Mitchell, C. A., Dougher, T. A. O., Nielsen, S. S., Belury, M. A., and Wheeler, R. M. (1996). "Costs of Providing Edible Biomass for a Balanced Vegetation Diet in a Controlled Ecological Life Support System," in Plant in Space Biology. Inst. Genetic Ecology. Editor H. Suge (Sendai, Japan: Tohoku Univ.), 245-254.

Morrow, R. C., Duffie, N. A., Tibbitts, T. W., Bula, R. J., Barta, D. J., Ming, D. W., et al. (1995). Plant Response in the ASTROCULTURE Flight Experiment Unit. SAE, Technical Paper 951624. doi:10.4271/951624

Morrow, R., Crabb, T., and Lee, M. (2004). "Evolution of Space-Based Plant Growth Systems from Research to Life Support," in Space 2004 Conference and Exhibit, San Diego, CA, Sept, 2004, 6022. doi:10.2514/6.2004-6022

Morrow, R., Richter, R., Tellezy, G., Monje, O., Wheeler, R., Massa, G., Dufour, N., and Onate, B. (2016). "A New Plant Habitat Facility for the ISS," in 46th International Conference on Environmental Systems, ICES-2016-320, Vienna, Austria, July.

Myers, J. (1954). Basic Remarks on the Use of Plants as Biological Gas Exchangers in a Closed System. J. Aviation Med. 25, 407-411. doi:10.1016/s0096-0217(16) 30036-x

Nakamura, T., Van Pelt, A. D., Yorio, N. C., Drysdale, A. E., Wheeler, R. M., and Sager, J. C. (2009). Transmission and Distribution of Photosynthetically Active Radiation (PAR) from Solar and Electric Light Sources. habitation (elmsford) 12, 103-117. doi:10.3727/154296610x12686999887481

Paul, A.-L., Daugherty, C. J., Bihn, E. A., Chapman, D. K., Norwood, K. L. L., and Ferl, R. J. (2001). Transgene Expression Patterns Indicate that Spaceflight Affects Stress Signal Perception and Transduction in Arabidopsis. Plant Physiol. 126, 613-621. doi:10.1104/pp.126.2.613

Perchonok, M., Douglas, G., Cooper, M., and Center, L. B. J. S. (2012). Evidence Report: Risk of Performance Decrement and Crew Illness Due to an Inadequate Food System. Houston, TX: NASA Johnson Space Center.

Pilgrim, A. J., and Johnson, S. P. (1962). Investigation of Selected Higher Plants as Gas Exchange Mechanisms for Closed Ecological Systems. Seattle WA: Boeing Company.

Porterfield, D. M., Neichitailo, G. S., Mashinski, A. L., and Musgrave, M. E. (2003). Spaceflight Hardware for Conducting Plant Growth Experiments in Space: The Early Years 1960-2000. Adv. Space Res. 31, 183-193. doi:10.1016/s0273-1177(02)00752-4

Richards, J. T., Edney, S. L., Yorio, N. C., Stutte, G. W., Cranston, N., Wheeler, R. M., et al. (2004). Effects of Lighting Intensity and Supplemental CO2 on Yield of Potential Salad Crops for ISS. SAE, Technical Paper No. 2004-01-2296. doi:10.4271/2004-01-2296

Romeyn, M., Spencer, L. E., Massa, G. D., and Wheeler, R. M. (2019). "Crop Readiness Level (Crl): A Scale to Track Progression of Crop Testing for Space," in International Conference on Environmental Systems ICES-2019-342, Boston, MA, July.

Salisbury, F. B., and Clark, M. A. Z. (1996). Suggestions for Crops Grown in Controlled Ecological Life-Support Systems, Based on Attractive Vegetarian Diets. Adv. Space Res. 18, 33-39. doi:10.1016/0273-1177(95)00859-d

Salisbury, F. B., Gitelson, J. I., and Lisovsky, G. M. (1997). Bios-3: Siberian Experiments in Bioregenerative Life Support. BioScience 47, 575-585. doi:10.2307/1313164

Schuerger, A. C., Amaradasa, B. S., Dufault, N. S., Hummerick, M. E., Richards, J. T., Khodadad, C. L., et al. (2021). Fusarium Oxysporum as an Opportunistic Fungal Pathogen on Zinnia Hybrida Plants Grown on Board the International Space Station. Astrobiology 21 (9), 1029-1048. doi:10.1089/ast.2020.2399

Shaw, L. A., Garr, J. D., Gavin, L. L., Matty, C. M., Ridley, A., Salopek, M. J., and Toon, K. P. (2020). "International Space Station as a Testbed for Exploration Environmental Control and Life Support Systems-2020 Status," in International Conference on Environmental Systems ICES-2020-299, Virtual Conference, July.

Spencer, L. E., Sirmons, T. A., Romeyn, M. W., and Wheeler, R. M. (2021). "Production, Nutrition, and Organoleptic Analysis of Solanaceous Crops for Space," in International Conference on Environmental Systems ICES-2021268, Virtual Conference, July.
Spencer, L. E., Hummerick, M., Stutte, G., Sirmons, T., Graham, T., Massa, G. D. and Wheeler, R. M. (2019). "Dwarf Tomato and Pepper Cultivars for Space Crops," in International Conference on Environmental Systems ICES-2019164, Boston, MA, July.

Spencer, L. E., Romeyn, M. W., Wheeler, R. M., Massa, G. D., and Mickens, M. A. (2020). "Effects of Supplemental Far-Red Light on Leafy green Crops for Space," in International Conference on Environmental Systems ICES-2020-380, Virtual Conference, July.

Steinberg, S. L., Ming, D. W., and Henninger, D. (2002). Plant Production Systems for Microgravity: Critical Issues in Water, Air, and Solute Transport through Unsaturated Porous Media. NASA Technical Memorandum 2002-210774. NASA Tech Mem, Johnson Space Center

Stutte, G. W., Monje, O., Goins, G. D., and Tripathy, B. C. (2005). Microgravity Effects on Thylakoid, Single Leaf, and Whole Canopy Photosynthesis of dwarf Wheat. Planta 223, 46-56. doi:10.1007/s00425-005-0066-2

Subbarao, G. V., Wheeler, R. M., Stutte, G. W., and Levine, L. H. (1999). How Far Can Sodium Substitute for Potassium in Red Beet? J. Plant Nutr. 22, 1745-1761. doi:10.1080/01904169909365751

Ward, C. H., Wilks, S. S., and Craft, H. L. (1970). Effects of Prolonged Near Weightlessness on Growth and Gas Exchange of Photosynthetic Plants. Dev. Ind. Microbiol. 11, 276-295.

Wheeler, R. M. (2017). Agriculture for Space: People and Places Paving the Way. Open Agric. 2 (1), 14-32. doi:10.1515/opag-2017-0002

Wheeler, R. M. (2002). Horticulture for mars. Acta Horticulturae 642, 201-215. doi:10.17660/ActaHortic.2004.642.22

Wheeler, R. M., Mackowiak, C. L., Stutte, G. W., Yorio, N. C., Ruffe, L. M., Sager, J. C., et al. (2008). Crop Productivities and Radiation Use Efficiencies for Bioregenerative Life Support. Adv. Space Res. 41, 706-713. doi:10.1016/j.asr.2007.06.059

Wheeler, R. M., and Strayer, R. F. (1997). Use of Bioregenerative Technologies for Advanced Life Support: Some Considerations for BIO-Plex and Related Testbeds. NASA Technical Memorandum 113229

Wright, B. D., Walter C. Bausch, W. C., and William M. Knott, W. M. (1988). A Hydroponic System for Microgravity Plant Experiments. Trans. Amer. Soc. Agric. Eng. 31, 440-446. doi:10.13031/2013.30728

Yorio, N. C., Goins, G. D., Kagie, H. R., Wheeler, R. M., and Sager, J. C. (2001). Improving Spinach, Radish, and Lettuce Growth under Red Light-Emitting Diodes (LEDs) with Blue Light Supplementation. HortSci 36, 380-383. doi:10.21273/hortsci.36.2.380

Zabel, P., Bamsey, M., Schubert, D., and Tajmar, M. (2016). Review and Analysis of over 40 Years of Space Plant Growth Systems. Life Sci. Space Res. 10, 1-16. doi:10.1016/j.lssr.2016.06.004

Zhen, S., and Bugbee, B. (2020). Substituting Far-Red for Traditionally Defined Photosynthetic Photons Results in Equal Canopy Quantum Yield for $\mathrm{CO} 2$ Fixation and Increased Photon Capture During Long-Term Studies: Implications for Re-Defining PAR. Front. Plant Sci. 11, 1433. doi:10.3389/ fpls.2020.581156

Zhou, W., Bula, R. J., and Duffie, N. A. (1998). Performance Evaluation of the Commercial Plant Biotechnology Facility. SAE, Technical Paper No. 981666. doi:10.4271/981666

Conflict of Interest: Author LES is employed by Amentum Services, Inc.

The remaining authors declare that the research was conducted in the absence of any commercial or financial relationships that could be construed as a potential conflict of interest.

Publisher's Note: All claims expressed in this article are solely those of the authors and do not necessarily represent those of their affiliated organizations, or those of the publisher, the editors and the reviewers. Any product that may be evaluated in this article, or claim that may be made by its manufacturer, is not guaranteed or endorsed by the publisher.

Copyright (ㄷ 2021 Johnson, Boles, Spencer, Poulet, Romeyn, Bunchek, Fritsche, Massa, O'Rourke and Wheeler. This is an open-access article distributed under the terms of the Creative Commons Attribution License (CC BY). The use, distribution or reproduction in other forums is permitted, provided the original author $(s)$ and the copyright owner(s) are credited and that the original publication in this journal is cited, in accordance with accepted academic practice. No use, distribution or reproduction is permitted which does not comply with these terms. 